\title{
The making of oncology: The tales of false carcinogenic worms
}

\author{
K. Lalchhandama
}

Department of Zoology, Pachhunga University College, Aizawl 796oor, Mizoram, India

Cancer is a disease of antiquity. The Ancient Greeks were familiar with onkos (from which we have the term oncology)-tumour of all sorts. Hippocrates coined karkinos and karkinoma, our source of the words cancer and carcinoma. Of a plethora of carcinogens, parasitic worms (helminths) constitute a considerable health concern. Three trematodes, Clonorchis sinensis, Opisthorchis viverrini, and Schistosoma haematobium are now officially classified carcinogens. But the discovery of helminths as cancer-causing agents took wrong turns and marks an inglorious chapter in the history of science. The carcinogenicity of worms, vindicating Rudolf Virchow's reiztheorie (irritation theory) of cancer origin, was glorified in the scientific forefront by Johannes Fibiger in the 1910s. Discovery of a new nematode, which he proudly named Spiroptera carcinoma, and his subsequent demonstration that the parasite could induce stomach cancer in rats, earned Fibiger a retrospective Nobel Prize in Physiology or Medicine in 1926, and a lasting fame. But not in an appealing way. His achievement did not withstand the test of time. S. carcinoma was annulled as an invalid taxon in zoology-supplanted by Gongylonema neoplasticum-and eventually was branded as a non-carcinogenic agent.

Key words: Gongylonema neoplasticum; helminth; Fibiger; cancer; Nobel Prize.
Received 23 January 2017 Accepted 15 February 2017

*For correspondence $\square$ : chhandama@pucollege.edu.in

\section{Historical Backdrop}

The 1960 Nobel laureate in Physiology or Medicine Peter Medawar, himself venerated as the cleverest or wittiest man, did not hesitate to call the British-Indian polymath J.B.S. Haldane the cleverest man he had ever known. Haldane arguably was the most notorious scientist for wry wit and sense of humour. As cancer (rectal carcinoma, to be precise) took its toll on him, he still had the gut to jot down the poem Cancer's $a$
Funny Thing, which could have infuriated other cancer victims and those who are sympathetic to them. Published in the 21 February 1964 issue of the New Statesman, he jocularly recounted:

My final word, before I'm done,

Is "Cancer can be rather fun".

Thanks to the nurses and Nye Bevan

The NHS2 is quite like heaven

Provided one confronts the tumour

With a sufficient sense of humour. 
I know that cancer often kills,

But so do cars and sleeping pills;

And it can hurt one till one sweats,

So can bad teeth and unpaid debts.

A spot of laughter, I am sure,

Often accelerates one's cure. ${ }^{1}$

\section{It's all Greek}

But the Ancient Greeks never saw such funny side of cancer. They were evidently much troubled by the disease without ever knowing what it was that it was from them we have the very word cancer. If it were not for our devoted reverence of Hippocrates (c. $460-$ c. 370 BCE), cancer must have been known, and correctly too, as onkos (ӧүкоц). To the Ancient Greeks a familiar disease was onkos, by which they meant any form of tumours, having no knowledge on the distinction between benign (harmless) and malignant (cancerous) tumours. Onkos literally means a mass, bulk, volume, or load, referring to the burden of the disease. The term was more popularly in use in Greek theatres to denote a tragic mask, which signifies the psychic burden that befell the wearer. ${ }^{2}$ Hippocrates introduced a more technical term from which we have the word cancer. He was the first to note that tumours have characteristic arm-like projections from the main body of the breast cancer tissue, from which he was reminded of a crab-a decapod, not the bad -tempered kind-with its claws (appendages) spreading out (Figure 1). So, he gave the name crab in Greek. Able to distinguish, at least by general type, the different forms of tumours, he used the term karkinos (кó $\rho к ı v o \varsigma)$ for any nonhealing swelling or ulcerous formation, even haemorrhoids; whereas he used karkinoma $(\kappa \alpha \rho \kappa i v \omega \mu \alpha)$ reservedly for malignant and invasive tumours, i.e. true cancers. He also devised the term skiros (бkipós, modernised as scirrhus or scirrhous), meaning hardened or overgrown, to describe what would be benign tumours. ${ }^{3-5}$ Breasts, since then, form very much the centre of attraction, in the development of oncology.

It goes without saying that Hippocrates is
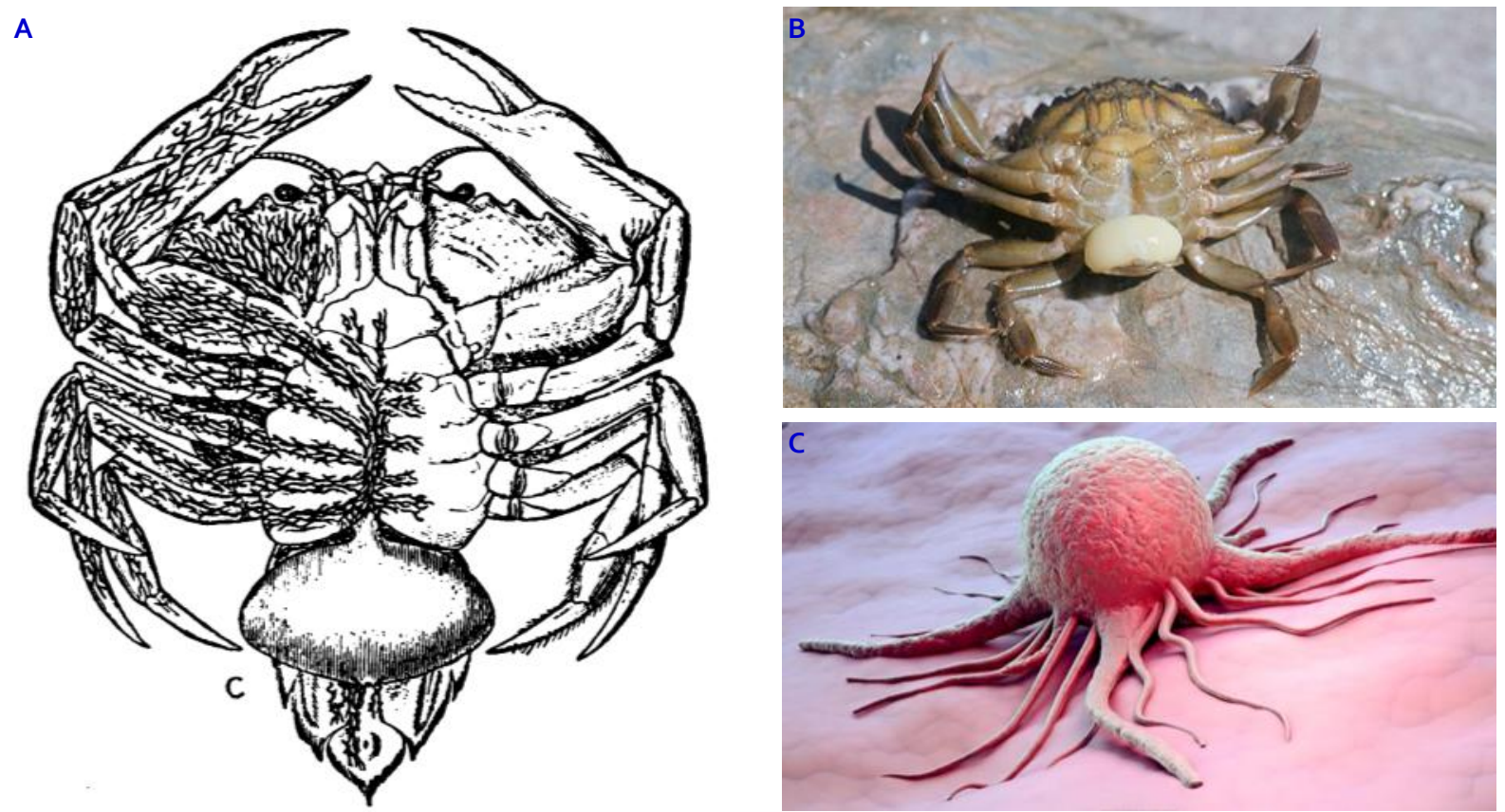

Figure 1 | Crabs and crab-like cancer cell. A. A crab infected by Sacculina, the bottom swelling is the tumour, drawing from Sambon (1924) $)^{9}$. B. A real crab with tumour due to Sacculina. C. A cancer cell (Mopic/Alamy at http://www.bbc.com/ earth/story/20160601-is-cancer-inevitable). 
deservedly idolised as the father of medicine, and had he been alive to see actual breast cancer cells under a microscope, he would have overjoyed at the precision of his created name as some cancer cells do look like crab. But only some, and it should be noted that most cancer cells do not look remotely like crab; hence, his was in large part a misnomer. But his influence pervaded. The Roman physician Aulus Cornelius Celsus (c. 25 BC - c. 50 CE) further elaborated the nature of cancer, particularly breast cancer, by which he introduced the Latinised name cancer (still a crab). ${ }^{6,7}$ The stronghold of the name was fortified by the most exalted physician of the Ancient World, Aelius Galenus (more famous simply as Galen, 129 - c. 200/c. 216 CE). Galen gave an extensive description of the crab-like nature upon examining an advanced stage of breast cancer, ${ }^{8}$ expressly commenting, "In the breasts we often find a tumour in size and shape closely resembling the animal known as a crab, for as in the latter the limbs protrude from either side, so in the tumour the swollen veins radiate from its edges and give a perfect picture of the crab." ${ }^{9}$ And more vividly by stating: "it appears at length with turgid veins shooting out from it, so as to resemble the figure of a crab; or as others say, because like a crab, where once it has got, it is scarcely possible to drive it away." ${ }^{10}$

With the emergence of English as the lingua franca of science, the analogy was universally appreciated and the name was retained. An English physician Peter Lowe in 1579 went so far as to describe the invasive and crab-likeness by saying that they "gnaweth, eateth and goeth like this fish." ${ }^{11}$ But the English-speaking people could not decide for centuries which terminology to adopt; cancer, cancre, chancre, and kanker, all from the same etymology, were indiscriminately applied. But in the end cancer won. As to onkos, it slipped away silently in history; perchance sympathy of the more original Greek, the branch of cancer study is oncology.

It is zoologically interesting to reiterate Galen's description as an apt portrayal of the structure of breast cancer, because it is a spot-on elucidation of the structure of a crab infected by another crustacean, Sacculina (Figure 1). First described by a British naturalist John Vaughan Thompson in 1838, Sacculina is a type of barnacle that lives as free-living larva but as it matures, it sheds off its body covering (cuticle) and parasitise the crabs. First, it penetrate the crab body, and forms a new cuticle that projects out rootlike suckers. At this stage, it is known as Sacculina interna. It grows and more and more like a tumour, and gradually force the crab body to atrophy (disintegrate). It finally takes over the entire body to become a sexually mature Sacculina externa. ${ }^{12,13}$ Breast cancer develops much in the same way. The analogy of cancer with crab is therefore not a simple likeness of the crab with its appendages, but the way Sacculina invades over it as well.

\section{The Groundwork Theories}

His contemporary scientists did not admire the bulwark German physician Rudolf Virchow as the Pope of medicine for nothing. His contribution to biology for the progress of humankind is multitudinous, although he had a tainted stance of intensely objecting to the germ theory of diseases and Charles Darwin's theory of evolution. He was the first to actually infer that cancer is not about just crab, and coined the name leukämie (a German word for blood disease, but later anglicised to leukemia) in 1847. He was the first to observe and correctly describe two years earlier in 1845 the blood disease as a type of cancer. $^{14}$ (Although it was simultaneously and independently discovered by an English physician John Hughes Bennett.) ${ }^{15} \mathrm{He}$ was also the first to describe chordoma, a tumour of the clivus at the base of the skull, in $1857 .{ }^{16}$ He was also the principal physician to Kaiser Frederick III, the German Emperor. A day after the Kaiser's death on 15 June 1888, Virchow performed an autopsy and confirmed that the Kaiser had epidermal carcinoma of the larynx. ${ }^{17}$ With such an erudition and scientific standing, his theory on the aetiology of cancer was bound for serious consideration. Introducing it in 1858 as reiztheorie, literally irritation theory, Virchow postulated 
that cancers are produced due to chronic irritation (now understood as inflammation) of tissues. ${ }^{18}$ Contradicting his mentor Johannes Müller who had propounded in 1838 the theory that cancer cells originate from special cells called blastema, he alluded cancer cells as nothing more than normal cells which have gone awry as a result of undesirable irritation. Although the cellular and molecular processes have much more intricate details, his idea is fundamentally true. ${ }^{19}$ In fact, his irritation theory laid the foundation for research on tumour promoters, such as an array of cytokines and their receptors, inflammatory cells, and antigen presenting cells. $^{20,21}$

Ever since Virchow, up to the early 1900s when cell biology was at its infancy, theories on cancer overflowed with alluring hypotheses, ludicrous speculations, and disparaging conjectures. The more outright but objectionable ideas on the cause of cancer range from accusation of solar radiation, radium, arsenic, food preservatives, to increasing use of machinery, the erect posture of humans, wearing of corset, beating of wife-all in the annals of medicine. A more sophisticated suggestion made by Holden Webb was the crystallisation of cholesterol in the cell, but then recommended a treatment regime of hypodermic injection of soap solution. Some physicians vehemently advocated that tumours were the tissue bits and parts of chicken, pork, and beef, commonly taken as food. Some would argue for vaccine that could interrupt the blood function, and portended that vaccination could elicit bovine features. Be reminded that when Edward Jenner introduced the name vaccine, he really meant cow, vacca in Latin, as he used the cowpox virus. The scientific obsession on cancer can be appreciated from far-fetched scientific names given to fungi and protozoan at the time, Rhopalocephalus carcinomatosus, Histosporidium carcinomatosum, and Cancriameba macroglossa. Without full-proof foundation, all have degenerated as invalid names, nomen illegitimum. ${ }^{9}$

The next best theory emerged from an unlikely source-botany. Scotland was plagued in 1798 with a sort-of-cancer disease of mostly cauliflower, although other cabbages were also affected. It was variously known as "club-root", "hanbury" and "finger-and-toe disease" (Figure 2). These vegetables suffered from tumours, becoming unsuitable for consumption, thereby leading to massive economic disaster. In 1878, a Russian botanist Mikhail Stepanovich Woronin deciphered the mysterious agent of the tumour. He discovered that in all the diseased plants, the root contained a protozoan, which he named Plasmodiophora brassicae. His experimental in-
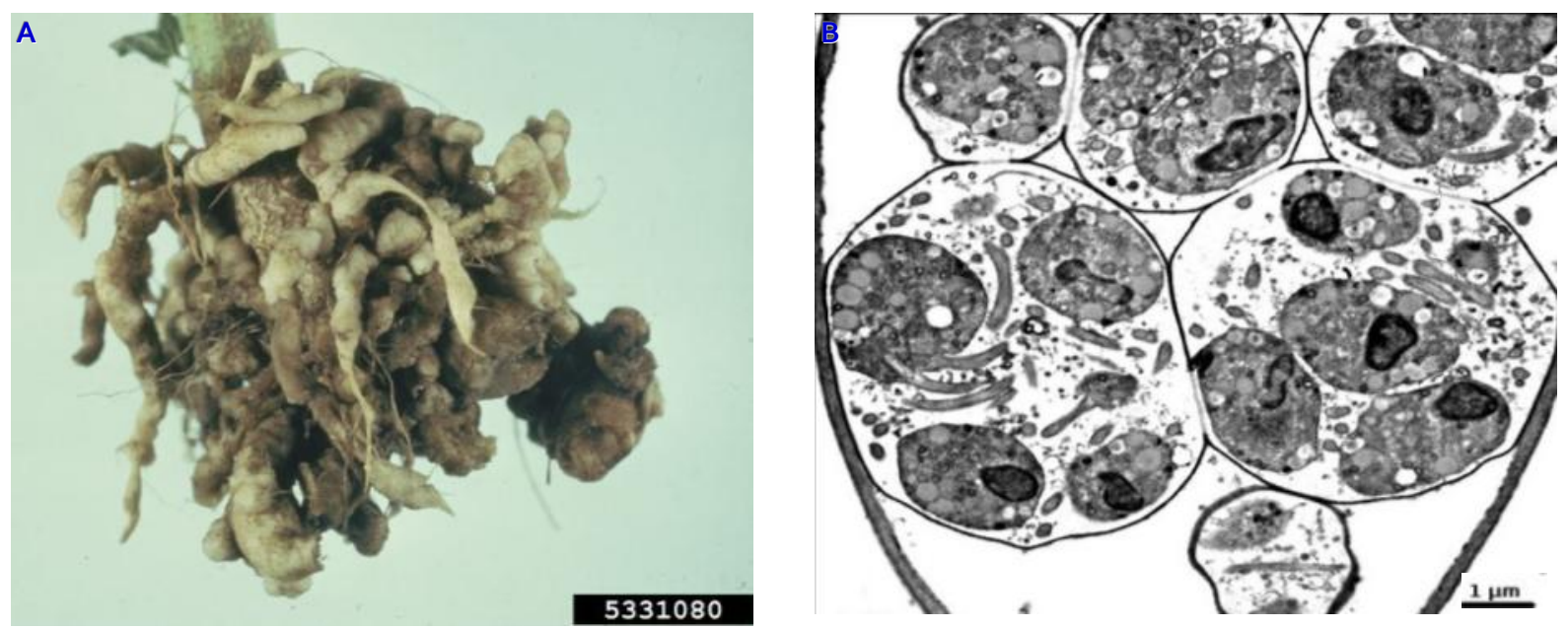

Figure 2 | Cabbage tumours due to Plasmodiophora brassicae. A. Brocolli club-root. B. Cross-section of root hair of cabbage showing zoospores inside the host cells. 
oculation of healthy vegetables with $P$. brassicae always resulted in tumour formation, thus, was a full proof of the tumour-causing capacity of the parasite. When the flagellated protozoans (two or more can infect a single cell) enter the root cells, they grow into large motile amoeboid forms. Then they fuse together forming a syncytium (combined structure). They start stimulating the host cells to rapidly divide that produce large tumours. When the dividing capacity of the initial host cell reaches its limit, it dies (by hyperplasia or hypertrophy), releasing the parasites that are free to infect the neighbouring cell, thereby causing a malignant disease. ${ }^{22}$ Then, a veritable analogy was preordained: cancer bodies described in human malignant tumours are supposed to be protozoa, and these unicellular organisms are considered to be the cause of cancer. Thus, was born the parasite (or infectious) theory of cancer: parasites must be the source of cancer.

A tinge of evidence in human case was first reported by a German physician Hugo Groth in 1864. According to his medical record, a German woman developed symptoms of rheumatism in the United States in 1856. He later diagnosed her symptoms as those of trichinosis (infection with the roundworm Trichina, now Trichinella). She returned to Germany after recovery, but was diagnosed with breast cancer in 1861. When the tumour was removed (mastectomised) and examined, a roundworm was identified inside the tumour. After three years, another bout of cancer (which had spread to her muscles) struck her, and she kicked the bucket in 1864. An autopsy revealed that roundworms were almost everywhere in her muscles. But Groth did not relate the roundworms as the source of cancer, instead inferred that the roundworms inside the tumours were coming from the nearby infected muscles. ${ }^{23,24}$ Another German physician Klopsch gave a report of a woman who had both trichinosis and breast cancer. The woman first consulted Klopsch in 1857 when she developed a tumour on her right breast. She related that she had been suffering from a prolonged symptom of muscular pains. Particularly in 1842 , she experi- enced severe muscular and joint pains, associated with paralysis - the symptoms of trichinosis. That year, her two servants died of the same symptoms. She underwent mastectomy in 1863. After two years in 1865 , the cancer had spread to the surrounding tissues and were again removed. Biopsy of the muscles revealed the presence of calcified (solid mass of) roundworms. ${ }^{25-27}$ It was from such amassing knowledge, and his own discovery of tumours (called xyloma) in woody trees, that one of the most eminent naturalists in the field, James Paget promulgated a sensible prognostication in his Morton Lecture in 1885 , by saying, "I believe that microparasites, or substances produced by them, will some day be found in essential relation with cancers and cancerous diseases." ${ }^{\prime 28}$ His optimism would be proven correct in a series of discoveries, that eventually led to the most coveted award, the Nobel Prize, to one of its most awkward cases.

\section{The Worm, the (Great) Dane and the Nobel Prize}

To err is innately human, and the Nobel Committee is no exception. The Nobel Committee for Physiology or Medicine shied away from giving the 1925 and 1926 Nobel Prize in Physiology or Medicine because it found that none was deserving. ${ }^{29}$ But in an unexpected turn of events, the committee in 1927 realised that there was in fact someone who made a notable discovery. They must have really kicked their own shins so hard that the 1926 Nobel Prize was retrospectively awarded in 1927 to Johannes Fibiger (Figure 3) "for his discovery of the Spiroptera carcinoma". ${ }^{30}$ At the award presentation, Wilhelm Wernstedt, Dean of the Royal Caroline (Karolinska) Institute, bestowed him the highest of praises, declaring,

Fibiger's work has been the greatest contribution to experimental medicine in our generation... [Addressing Fibiger] your name will shine among the greatest, and you will remain a pioneer and a forerunner. $^{31}$ 
A glorious end to his career, as he died seven weeks after receiving the award, of cancer, the very disease he was trying to combat throughout his career.

In a series of erroneous events, that belated award was only a tip of the iceberg. Johannes Andreas Grib Fibiger was a Danish physician who had the outstanding privilege of studying under the German giants of medicine such as Emil von Bering (winner of the first ever Nobel Prize in Physiology or Medicine in 1901) and Robert Koch (a no less Nobel Prize in Physiology or Medicine laureate in 1905). Fibiger's discovery that rodent roundworms caused stomach cancer in rats was not entirely a scientific implausibility, or a resentful experimental blunder, especially at the heyday of unsubstantiated theories on the aetiology of cancer. In fact, a Director of the In-

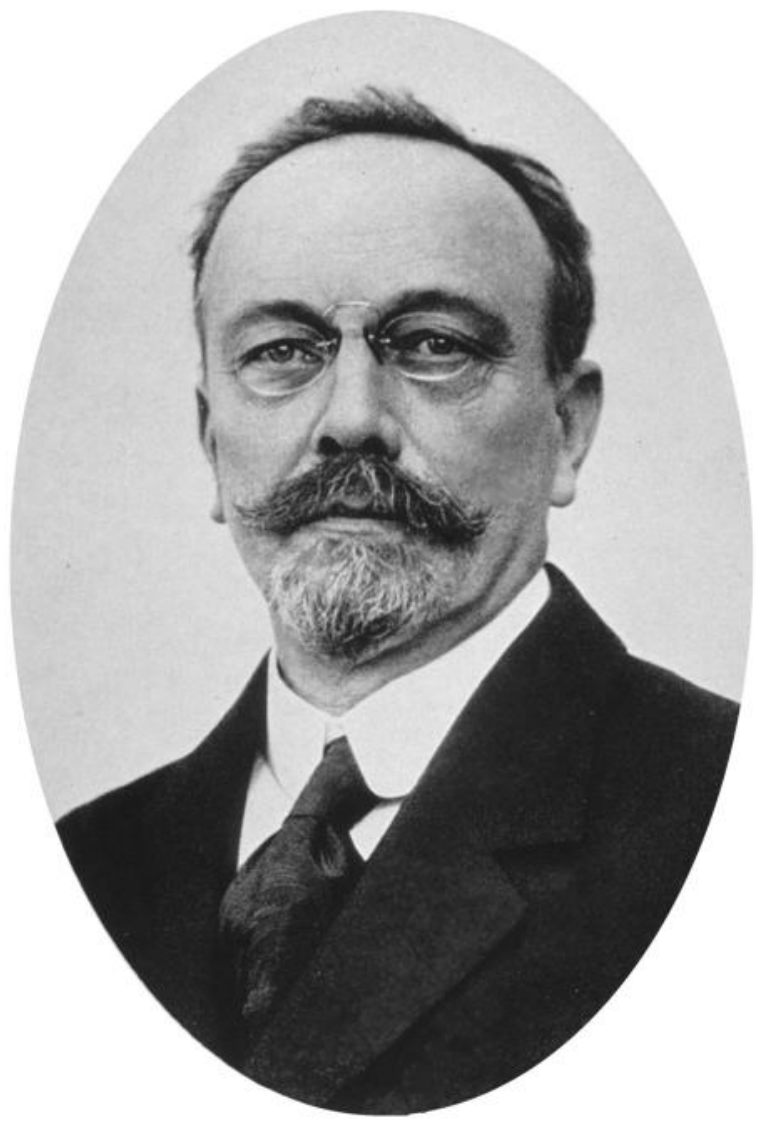

Figure 3 | Johannes Fibiger, the 1926 Nobel Prize in Physiology or Medicine laureate. stitute of Pathological Anatomy of the University of Copenhagen at a young age of 33, Fibiger had a well-known reputation for meticulousness, modesty and congeniality throughout his career. Historical assessment indicates that he was actually the one who laid down the foundation of a crucial method in medical science called randomised trial in 1898, from his investigation on the treatment of diphtheria. ${ }^{32}$

\section{Discovery of a carcinogenic nematode}

In 1907, Fibiger dissected three wild rats captured from Dorpat (officially Tartu) in Estonia, which he found were having gastric papillomas (epithelial tumour). Some tumour appeared to be malignant. To his utter puzzlement, he recovered hitherto unknown nematodes and their eggs from the papillomatous squamous epithelium (Figures 4-7). ${ }^{33}$ Was there a link between the tumours and the nematodes? To Fibiger, there definitely was. Immensely enthused by the idea, he rummaged through all available scientific literature related to the subject. He luckily came across a rather small article in 1878 reporting that the nematodes were found in rats and cockroaches. It was a report of French biologist M. Osman Galeb, who discovered the life cycle of a nematode Filaria rhytipleurites between rats and cockroach (Periplaneta orientalis). He had demonstrated that the larvae (the asexual forms) of the nematode were transmitted from the cockroach to rats, in which they grow into adults (sexual forms). ${ }^{34}$ But Fibiger tried in vain to experimentally verify his idea. He could not find a single rat having cancer even after catching and dissecting over a thousand wild rats. However, he did find nematode-infected rats from a sugar refinery adjacent his institute. He caught 61 rats, of which 40 of them were parasitised with nematode. $^{35}$ To support his carcinogenic-nematode notion, he found that seven of the infected rats had stomach tumour, which he never doubted as gastric cancer. To foster his assumption, he caught many cockroaches infected with the larvae of the nematodes in the same refinery. ${ }^{36,37}$ What could be more obvious than to uphold the 


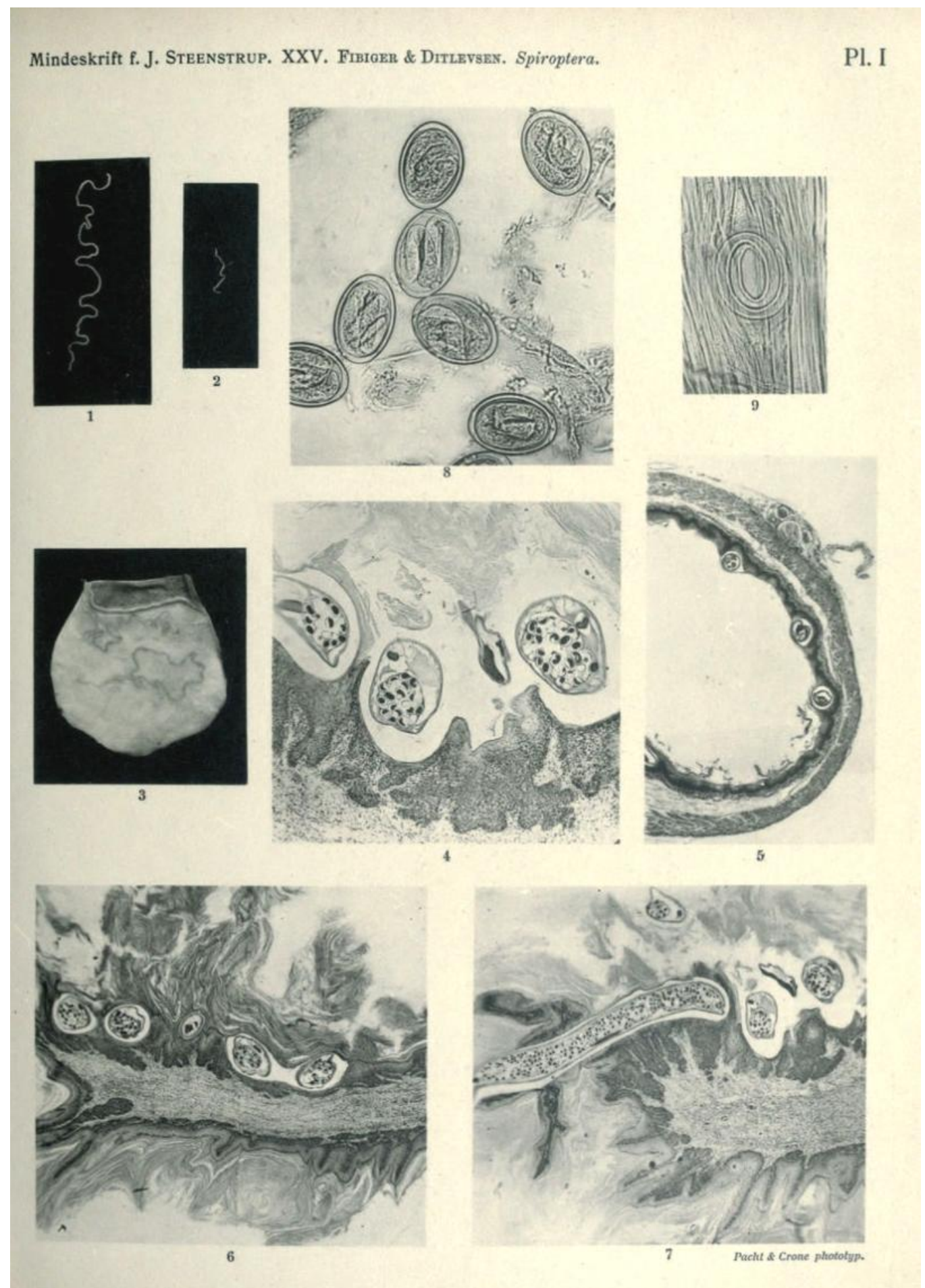

Figure 4 | Spiroptera as originally described by Fibiger (1913). ${ }^{39,41} 1$ - Female. $2-$ Male. 3-9-Sections of rat's stomach containing nematode and the eggs . 


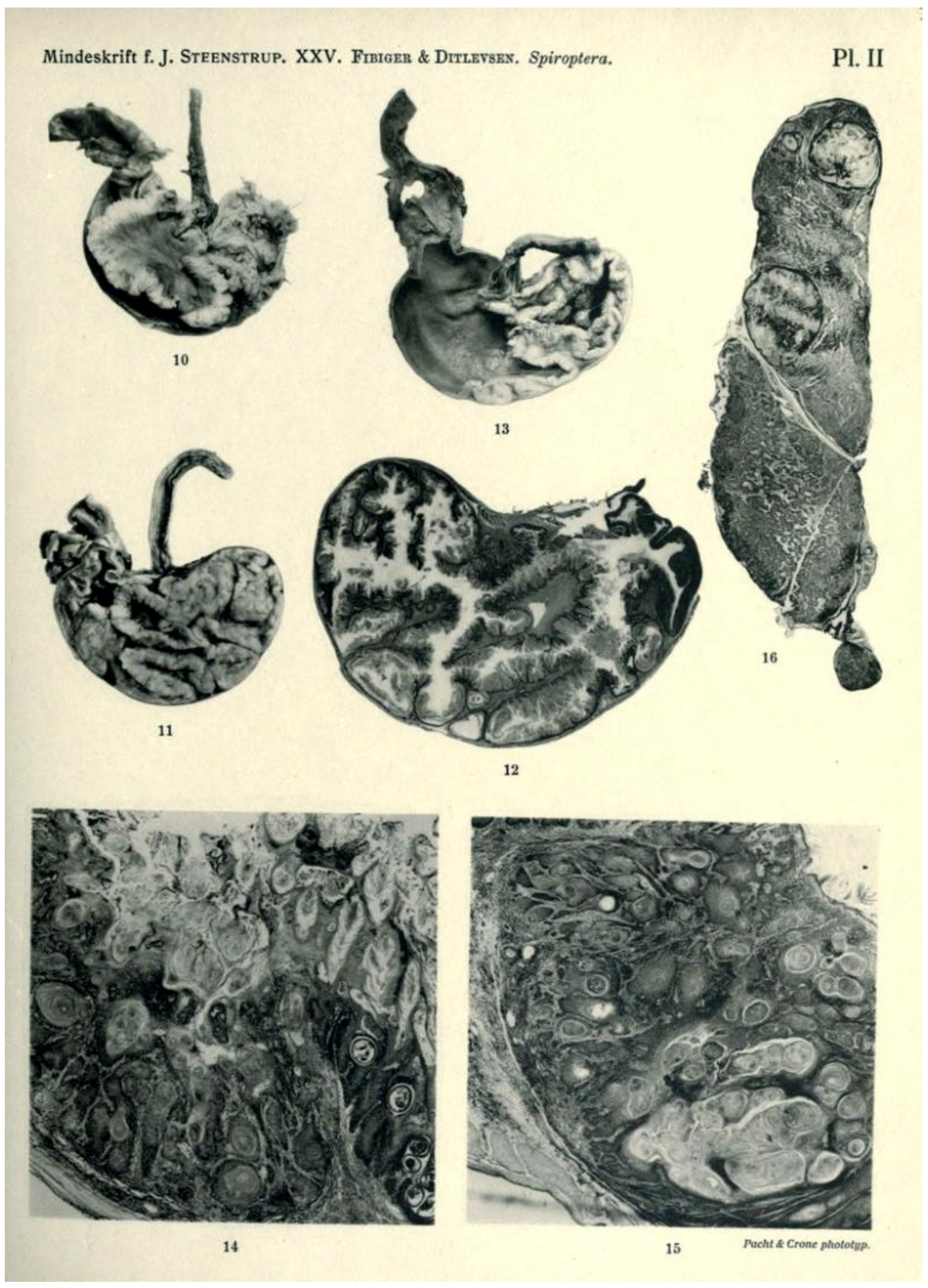

Figure 5 | Spiroptera as originally described by Fibiger (1913). ${ }^{39,41} 10-16$ - Different tumours described as carcinomatous tumours in rat. 


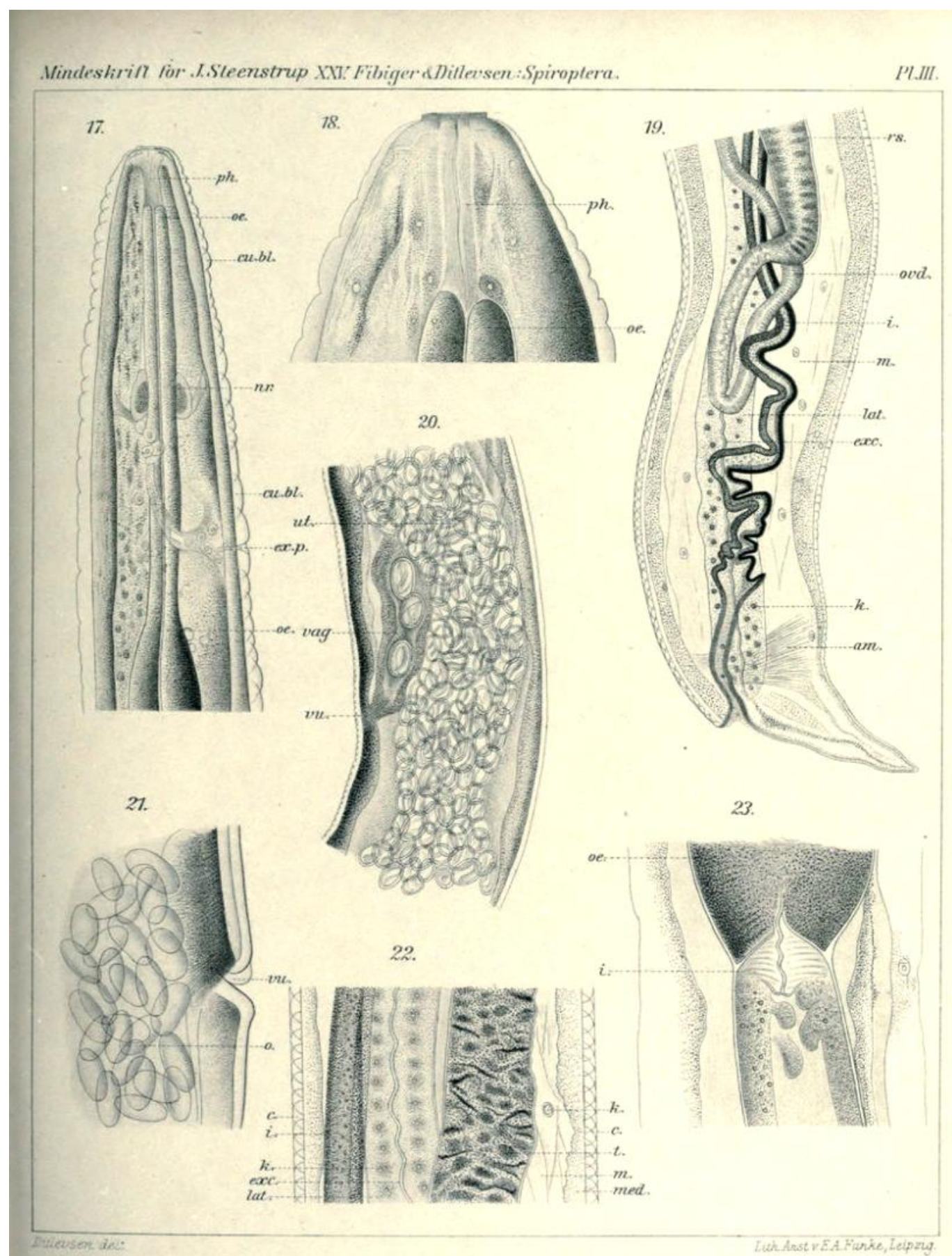

Figure 6 | Spiroptera (Gongylonema) neoplasticum as originally described by Fibiger and Ditlevsen (1914). ${ }^{41} 17,18,22,23-M a l e .19-21-F e m a l e$. 


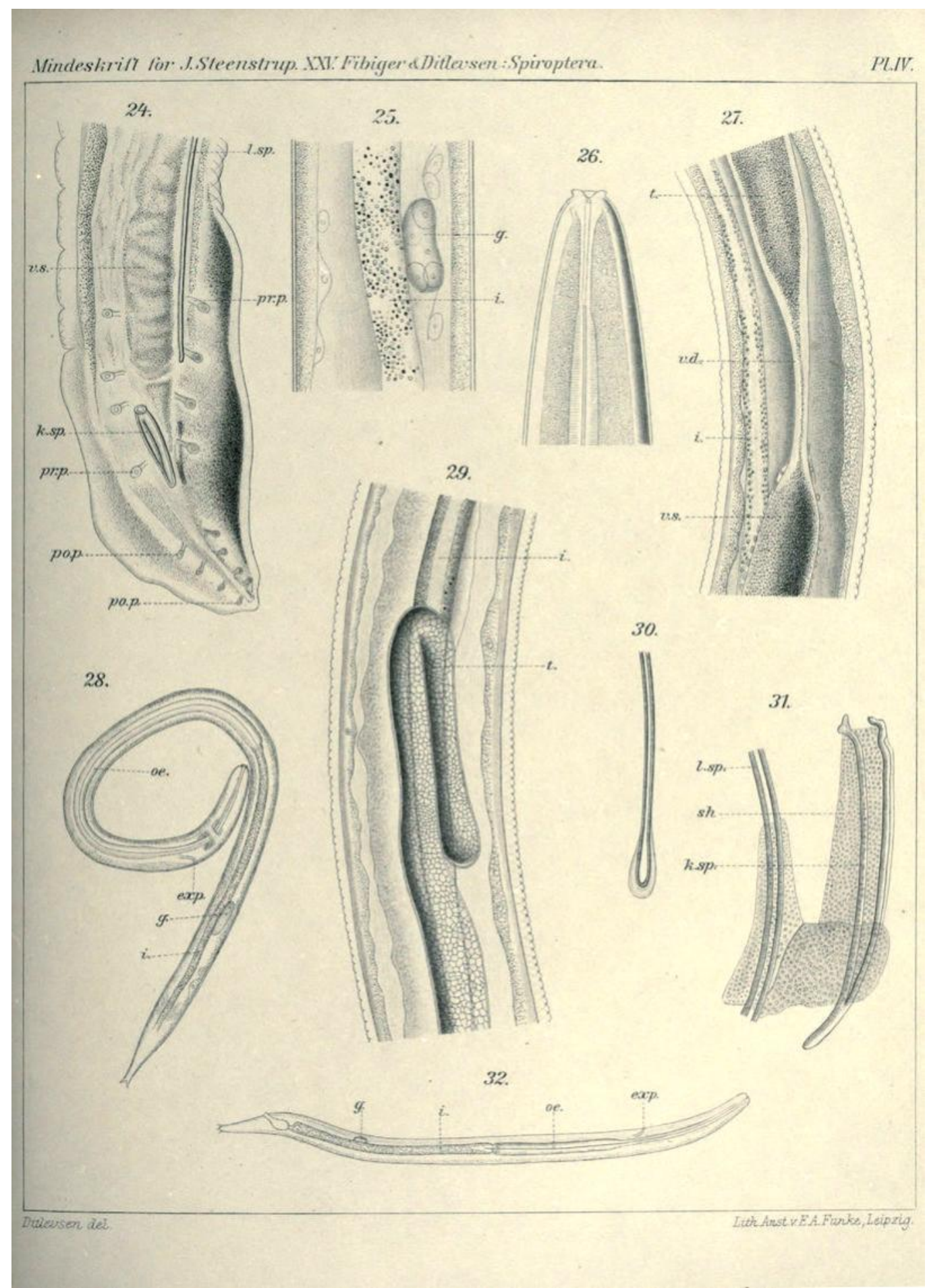

Figure 7 | Spiroptera (Gongylonema) neoplasticum as originally described by Fibiger and Ditlevsen (1914). ${ }^{41}$ 24, 27,29,30,31-Male. 25,26,32-Larvae from cockroach. 28-Larva from rat. 
hypothesis that the nematodes infect the cockroaches, and from them the rats, in which they produce cancer?

\section{Experimental proofs}

Fibiger then performed the obvious experiment. He fed healthy rats with cockroaches that are infected with nematode larvae. After toiling laboriously for over half a decade, he could triumphantly report in 1913 in a series of three papers that he successfully induced stomach cancer in rats by feeding the rats with nematode -infected cockroaches. ${ }^{38-40} \mathrm{He}$ also presented his findings before the Académie Royale des Sciences et des Lettres de Danemark (Royal Danish Academy of Sciences and Letters), and Troisième Conférence Internationale pour l'Étude du Cancer (Third International Conference for Researches in Cancer) at Brussels the same year. He even made a numerical assessment that the number of rats developing cancer was proportional to the number of cockroaches they were fed. In terms of parasitology, cockroach was clearly the intermediate host of the nematode in which larval development occurs, and rat, the definitive host in which adult worm reside to produce the pathological symptoms. With the help of fellow Danish Hjalmar Ditlevsen, a zoologist at the Zoological Museum of the University of Copenhagen, Fibiger made a formal description and christened the new nematode species Spiroptera (Gongylonema) neoplastica in 1914 for obvious reason (neoplastic for tumour). ${ }^{41}$ It was then relatively a simple solution to extend his conclusion in human terms as well, that gastric cancer in humans is also due to nematode. The implication of his discovery at the time was hugely important because the cause of stomach cancer was not known, making the medical community in fits of unremitting debates. He was immediately inducted as member to the Svenska Läkaresällskapet (Swedish Society of Medicine), the first of his numerous honours that would follow during his lifetime. His achievement was heralded as the dawn of the new era in cancer research. ${ }^{37}$
In summary of a decade of Fibiger's experiments, it can be said that he was particularly successful in inducing squamous cell carcinoma (cancer of the epithelial cells) in stomach of rats. $50 \%$ of his experimental rats developed squamous cell carcinoma in the stomach and intestine after they were infected with the roundworm. Among the cancerous rats, about $25 \%$ of them indicated metastasis (cancer cells invading other cells). In his later experiments, he did what would be conclusive of a real cancer, transplanting the cancer cells to healthy individuals in which they induce cancer. But he was not so successful with mice, in which he managed to induce cancer only in three out of hundreds. ${ }^{42} \mathrm{He}$ completely failed with wild mice even using very high amount of infection (800 larvae in a mouse). But in two mice, there was mammary gland carcinoma without any tumour in the stomach. In his 1923 experiments, he fed the larvae instead of injecting, and found that only one mouse developed mammary gland carcinoma. He explained that the negative results probably must be due to the specificity of the roundworm for a specific host or individual dispositions, and that young rats and mice are more susceptible. ${ }^{43,44}$

\section{Furtber evidences}

Fibiger's evidences were quite compelling and from them it is hard to doubt that parasitic cause of cancer was a mere coincidence. He was never looked down with suspicion. From his several experiments with different pathogens, a French physician Amédée Borrel had suspected in 1906 that helminths could have been agents of some cancers. He could transplantation of liver cancer in rats which was closely associated with the larvae (called Cysticercus fasciolaris) of the tapeworm Taenia crassicolis, now $T$. taeniaeformis. He also found roundworms alongside the mammary carcinoma of mice, and questioned whether or not the parasites were the aetiological factors or that they carry some virus that can cause cancer. ${ }^{45,46}$ By that time the carcinogenic property of the trematode Bilharzia haematobium has earned great infamy. It was no wonder 
that exacerbated by a report of an undefined Gongylonema species infecting a sixteen-yearold American girl in $1916,{ }^{47}$ and that G. scutatum of sheep and cattle could be responsible widespread cancer in rural farming communities, it was widely and wildly suspected that those roundworms were the culprits of human cancer. ${ }^{48}$ Bolstering Fibiger's experimental conclusion, two Japanese scientists Katsusaburo Yamagiwa and Koichi Ichikawa reported a vital empirical explanation in 1918. They supported Fibiger's experiments by invoking the first theory on cancer development proposed by Virchow, ${ }^{49}$ by concluding that "the soundness of Virchow's irritation hypothesis has been demonstrated [by Fibiger] experimentally for the first time." They even showed that mechanical or chemical irritation was the main stimulus of cancer, especially the painting of coal-tar upon the inner surface of the ear was the most effective in inducing carcinoma in rabbits. ${ }^{50}$ Between 1918 and 1924 a number independent experiments confirmed the cancer-inducing effect of coal tar in mice. ${ }^{51}$ It is now known that coal tar contains polycyclic aromatic hydrocarbons (PAHs) that are carcinogenic, and are serious threat to the health of factory workers. ${ }^{52,53}$ To further lend credence, George W. McCoy reported in 1909 from the Federal Plague Laboratory at San Francisco that wild rats have different types of cancers, and that the liver cancer is particularly caused by the larval form ${ }^{54}$ which is later proven to a be fact. ${ }^{55,56}$

\section{The Nobel Prize Controversy}

As discussed, Fibiger was incessantly nominated for the Nobel Prize for Physiology or Medicine since 1920. In fact, he received a staggering 18 nominations starting from 1920 . He received two nominations in $1926 .{ }^{57}$ One of the nominations also included Katsusaburo Yamagiwa. Folke Henschen and Hilding Bergstrand were appointed to make the assessment. In conclusion, Henschen remarked was that "the experimental carcinoma is worthy of the Nobel Prize. It should therefore be just if the prize would be divided between Johannes
Fibiger, the discoverer of the experimental spiroptera carcinoma, and Katsusaburo Yamagiwa, the discoverer of the experimental tar carcinoma." But Bergstrand was apprehensive, and concluded that "an experimental confirmation of a previously known fact... can, in this case, not be considered... that one cannot, at this point, find much support for the possibility that the work of Fibiger and Yamagiwa will have great importance in the solving of the riddle of cancer. Under such circumstances I do not consider these discoveries worthy of the Noble Prize." The frigid opinions prompted the indecisive Nobel Committee to hold the prize for 1926, and polemic letters poured in from the two parties. Seven nominations were filed for Fibiger in 1927. But there were two other formidable nominees, Otto Heinrich Warburg, for his works of cancer metabolism and respiratory enzymes, and Julius Wagner-Jauregg, for the discovery of malaria treatment. Henschen and Bergstrand, with irreconcilable personae, were again appointed assessors. The history of discord repeated itself between them. Henschen by then had favoured only Fibiger, ignoring Yamagiwa. To balance out any odd decision, a third assessor Einar Hammersten was appointed and he was quick to support Henschen's observation. Based on their recommendation, the Nobel Committee decided to award the 1926 prize jointly to Fibiger and Warburg, and the 1927 prize to Wagner-Jauregg. But the assembly of the Karonliska Institute, the supreme authority, disagreed to the recommendation of Fibiger and Warburg for undisclosed reason, and eliminated Warburg. Fibiger became the sole winner. (Warburg had to wait until 1931 to wear his Nobel laurel.) ${ }^{37}$ Erling Norrby, who had served as the Permanent Secretary of the Royal Swedish Academy of Sciences and Professor and Chairman of Vorology at the Karolinska Insitute, declared Fibiger's Nobel Prize as "one of the biggest blunders made by the Karolinska Institute. ${ }^{158}$

\section{Refutation}

The Nobel Prize was a fitting recognition of 
such an immensely vital-sounding discovery, befitting the very will of Alfred Nobel that the discovery "conferred the greatest benefit on mankind," but only if it were true. Fibiger died in glory (but ironically of cancer) in 1928, and humankind will regret not verifying his experimental results during his lifetime. No record of replication or further studies of his works exists. His contemporary scientists are to blame. Perhaps, the only stringent criticism was by F. D. Bullock and G. L. Rohdenburg who laboriously described in 1918 that the nematode might not have produced cancer, or in fact, they were not cancer at all. They defended that the acclaimed cancer in the rat stomach (squamous carcinoma) was only tumour in the truest sense, because the squamous epithelium is known to be highly active cells in terms of cell division. Hence, they are prone to rapid proliferation to form tumours. Further, the alleged carcinoma in Fibiger's rats never spread to the underlying tissues, as cancer cells should. ${ }^{59}$ (To which Fibiger passionately defended his position, stating: "That these tumors are true carcinomata cannot, thus, be doubted, and the fact that they may occur in younger animals does not diminish our right to range them among the true malignant neoplasms." ${ }^{42}$ ) A British physicians Richard Douglas Passey, with his colleagues A. Léese, and J.C. Knox made a surprising report in 1935 that $S$. carcinoma do not cause cancer in rats. They demonstrated that "rats fed on white bread or on a diet deficient in vitamin $\mathrm{A}$ and infected with cockroaches carrying the larvae" of the nematode cannot produce gastric cancer. They concluded that Fibiger could have been confused metaplasia (a benign tumour and not dangerous, or cancerous) with malignant neoplasia (real cancer), which in fact can be readily produced by vitamin $\mathrm{A}$ deficiency ${ }^{60}$ By then the cellular nature of harmless tumours and true cancers was firmly established. In 1937, W. Cramer, based on his two series of experiments carried out at an interval of ten years, also asserted that Fibiger's tumour could not be a true cancer. ${ }^{61}$ The final blow came in 1952 when Claude R. Hitchcock and E. T. Bell repeated Fibiger's experiments using advanced microscopy and histology, and decisively found that the tumours induced by the nematode in rats were metaplasia, not cancer. All cancer-like tumours detected were due to vitamin A deprivation. ${ }^{62}$ In 1962, a South African physician A.G. Oettlé, with the help of Johannes Clemmesen at Copenhagen, re-examined Fibiger's samples, and came to the conclusion that Fibiger did not induce cancer, and that the gastric lesions were pseudoepitheliomatous hyperplasia; the lymphnodal "metastases" were squamous metaplasia in epithelial inclusions; and the lung "metastases" were in fact squamous metaplastic lesions in bronchi, subjected to vitamin-A deficiency and bronchiectasis. ${ }^{63}$

As to the induction of tumour, it is now easily understood that vitamin $A$ is an essential dietary compound for normal cellular activities. It influences cell differentiation, proliferation, and apoptosis and play an important physiologic role in a wide range of biological processes. ${ }^{64}$ Fibiger used vitamin deficient rats in his experiments. In the year of Fibiger's Nobel Prize, an American physician Montrose T. Burrows made a series of observations that tumour tissues always have very low content of vitamin $A$, and that vitamin $A$ deficiency resulted in faster growth of cell. He concluded that rapid cell growth such as tumour formation is linked to vitamin A deficiency. ${ }^{65-68}$ At the same time a Japanese physician Yoshitomo Fujimaki demonstrated that rats treated with vitamin A-deficient diet easily developed stomach cancer (gastric carcinoma). ${ }^{69}$ But his microscopical studies were criticised. Research between 1926 and 1929 supported the observation that vitamin A deficiency could bring about metaplasia of epithelial cells in the gastrointestinal, respiratory and urinary tracts of rat. ${ }^{70}$ But not all were convinced, and some were arguing that the cancer could be due to secondary infection or other physiological abnormality. Particularly, the reports of Kanematsu Sugiura and Stanley R. Benedict in 1930 were critical of the whole idea. They failed to induce cancer in rats using vitamin A-deficient diet. ${ }^{71,72}$ A judicious experimentation was performed by an American physician Clifford Kuh in 1932. Using various amounts of vitamin A, 
making proper control for vitamin A-deficient diet, and transplantation of tumour in mice, he found that normal cell growth is not differently influenced by the amount of vitamin A, and that tumour development is inhibited by feeding with vitamin A. ${ }^{73,74}$ Clinical reports in 1937 and 1938 established that many cases of human gastric cancer were due to vitamin A deficiency. ${ }^{75-77}$

The complete review of Fibiger's works was published by Clemmesen in $1978 .{ }^{78}$ He not only re-analysed Fibiger's faulty claims, but also interviewed people associated with Fibiger, concluding that Fibiger was led to erroneous conclusion largely because of his enthusiastic interpretation of his data. Scientists have learned ever since to be more skeptical on unexpected discoveries, then learned to much that they were overtly skeptical as in the case of the discovery of the bacterium Helicobacter pylori as an agent of stomach ulcer. ${ }^{35}$ Two Australian physicians Barry Marshall and Robin Warren discovered that many stomach ulcer were due to infection with $H$. pylori, opposing the hitherto medical consensus that stomach ulcer is due to tobacco smoking and stress. The scientific community by and large flatly refused to believe, which angered Marshall to the extent that he drank the whole culture of the bacterium. His stomach ulcer revealed by endoscopy and subsequent cure with antibiotics needed no further proof. They just could not be denied of the 2005 Nobel Prize in Physiology or Medicine "for their discovery of the bacterium Helicobacter pylori and its role in gastritis and peptic ulcer disease." $36,79,80$

The remark by Paul D. Stolley and Tamar Lasky subtly sums up the account of Fibiger, going:

Fibiger's story is worth recounting not only because it teaches us about pitfalls in scientific research and reasoning, but also because it may provide perverse solace for those of us who will never receive the Nobel Prize (but, of course, deserve it). ${ }^{33}$

Amazingly, there never was anything untoward, or scientific malpractice, but only a preco- cious venture that led to a specious conclusion. By the standard of his time, Fibiger's works were phenomenal. In his defence, it can be stressed that he never claimed that $S$. spiroptera would cause cancer in humans. He prudently crafted his statements in his Nobel lecture, saying,

This therefore removes any shadow of a doubt that the Helminthes must be included among the causative agents of cancer... although the possibility of fortuitous coincidence cannot, of course, be entirely ruled out... Helminthes [referring to Schistosoma haematobium, Opisthorchis viverrini, and Clonorchis sinensis]... must be assumed to play a greater or lesser role in the development of tumors and cancers in humans... So far as can be ascertained, Gongylonema neoplasticum is never found in humans. ${ }^{44}$

To take it at face value, he was not entirely wrong. There are carcinogenic helminths-the three trematodes he set an example to are classified human Group 1 carcinogens. The Nobel Committee can also find solace themselves as the award was to Fibiber was "for his discovery of the Spiroptera carcinoma", and not explicitly for the carcinogenicity of the parasite in human beings. But then the lasting benefit to human welfare is missing, as noted, in the 1922 and 1923 rejection of Fibiger for the Nobel Prize, by Gunnar Hendrén of the Nobel Committee that the discovery was clearly not "for the maximum benefit of humanity. ${ }^{37}$ His obituary in The British Medical Journal ran with a closing remark, "All will agree that to Fibiger is due the honour for blazing the trail, ${ }^{\prime 81}$ but is was that very blaze that burnt down his reputation. As Allen B. Weisse (but attributing to someone else) sarcastically lamented, "Fibiger may have been barking up the wrong tree, but he was still a great Dane." ${ }^{82}$

\section{A Roundworm of Sinister Reputa- tion}

This is neither an overstatement nor an exag- 
geration, the factory-habitats of G. neoplasticum with its hosts had earned, all thanks to Fibiger, the notorious moniker "cancer houses" in medical community. ${ }^{46,83}$ It would be worthwhile recapping some of its (almost or mostly) forgotten zoological chronicles.

\section{The deplorable taxonomy}

It is perceptibly unclear as to why Fibiger had an inordinate affection for the binominal but invalid name Spiroptera carcinoma, he always used the name throughout his career. Medical scientists are (at least, were) often ignorant of the zoological basis of diseases and their pathogens. I cannot fathom a better example than the discovery of transmission of malaria, that eventually led to the first controversial Nobel Prize in Physiology or Medicine in 1902. An amateur (barely scraped through the bare minimum degree to join the Indian Medical Service) British Army Surgeon Ronald Ross made monumental discoveries. He found in 1897 that certain mosquitos could carry the human malarial parasite and thus acting as the disease vector. After a frustrating and disappointing service, he experimentally proved in 1898 that malarial parasite of bird is transmitted by mosquito from an infected to healthy ones. Was that directly beneficial to humankind? No. Ross never defined the species of the mosquito and of the malarial parasite. To a scientifically conscious and genius mind like Patrick Manson, Ross' mentor in fact, who developed the original mosquito-malaria theory, ${ }_{1}^{84}$ it was by no means conclusive that a bird malaria is similarly transmitted by mosquito in humans. It was he who confirmed it in an elegant experiment that it was so. ${ }^{85}$ To make Ross' credibility worse, a properly trained Italian physician-cumzoologist Giovanni Battista Grassi had a complete knowledge of the species of malarial parasites and the mosquito. In his 1891 book Studi di uno Zoologo Sulla Malaria he had given the classification of human malaria and their parasites such as benign tertian caused by Haemamoeba vivax (now Plasmodium vivax), malignant tertian caused by Laverania malariae (now P. falcipa- rum), and quartan caused by Haemamoeba malariae (now P. malariae). He also described the bird malaria Proteosoma praecox and using it demonstrated that they could be infected from one bird to another. In 1989, soon after Ross' triumphant publication, he reported that $P$. falciparum was specifically transmitted by a female mosquito (in his case, Anopheles claviger) in humans. ${ }^{86}$ But only Ross had the last laugh, bagging the 1902 Noble Prize.

It could have been for narcissistic reason that Fibiger cling on to the name $S$. carcinoma. Believing it to be a completely new species, he assigned it the genus Spiroptera in his 1913 papers. ${ }^{38-40} \mathrm{He}$ introduced its full name Spiroptera carcinomet in $1914 .{ }^{87}$ But he surreptitiously sought the help of a zoologist Ditlevsen, with whom he gave the formal scientific name. ${ }^{41}$ Ditlevsen was clearly aware of the nematode's characteristics by placing it under Gongylonema, the genus which was created by an Italian zoologist Raffaele Molin in 1854. Yet the final publication in 1914 dubiously mentioned it as Spiroptera (Gongylonema) neoplastica, egotistically reserving the new genus name for prominence and posterity. Fibiger had no hesitation in lucidly discounting the rules of the zoological nomenclature. As far as I can trace, perhaps in only two instances did ever he mention again Gongylonema. In his 1918 and 1920 papers, expressly describing how the nematode induced cancer, he inconsistently use the name Gongylonema neoplasticum (no one can break the zoological law with impunity, even by authority). ${ }^{88,89}$ It would not be entirely implausible to conjecture his fallout with Ditlevsen, as Ditlevsen revised the taxonomy in 1918 and rechristened it with a final and valid name Gongylonema neoplasticum. ${ }^{90} \mathrm{His}$ obsession with his own creation Spiroptera carcinoma was epitomised in his momentous Nobel Lecture titled "Investigations on Spiroptera carcinoma and the experimental induction of cancer", a scientific name that will not last, but yet will endure as a black stain as long as there are Nobel Prizes-the Nobel Committee bought it hook, line, and sinker, as his Nobel citation would give away. His lack of zoological persua- 
sion rings more profound in his Nobel Lecture, saying about the discovery of the new speciesone can sense a tone of dismay in the secondhalf of the sentence-saying,

It was given the name Spiroptera neoplustica [sic], which has since been changed to Gongylonema neoplasticum. ${ }^{44}$

\section{Of its biology}

The natural hosts of $G$. neoplasticum are rats of the species Rattus norvegicus and $R$. rattus. The adult roundworms are found in the squamous-celled epithelium of the anterior portion of the digestive tract, including the mouth, tongue, oesophagus and fundus. The body is of a typical roundworm, that is cylindrical and elongated with both ends attenuated. The body surface is covered by a thick cuticle, which is regularly striated. The anterior end is the mouth in the form of triangular aperture; but, unlike typical nematode, lack lips. There are small sensory organs called cephalic papillae, and cervical papillae are absent. Inside the mouth is followed by a short buccal cavity with a thin chitinous lining. The oesophagus is divided into two regions: an anterior portion, which is short and slender and passes abruptly into the posterior portion. The intestine is as thick as the anterior portion of the oesophagus, and terminates into a cloaca (anus). ${ }^{91,92}$

There is distinct sexual dimorphism. An adult male is relatively smaller, measuring $1.5 \mathrm{~cm}$ long $(0.74$ to $2 \mathrm{~cm})$, with a diameter of $0.1-0.16 \mathrm{~mm}$. Its posterior end is more pointed and slightly twisted containing cloaca and precloacal sucker on the ventral side. Around the cloacal region is eight pairs of caudal papillae, four in front of cloaca, and four behind. Two thread-like projections from the cloaca are called spicules. The left spicule is longer and about $0.6 \mathrm{~mm}$ long, while the right one is $0.08 \mathrm{~mm}$ long. The male reproductive system consists of a single testis, vas deferens, seminal vesicles, ejaculatory duct, two spicules, gubernaculum and bursa. Females are highly variable in size, with body size ranging from $4.5 \mathrm{~cm}$ to $11.5 \mathrm{~cm}$ in length, and $0.23 \mathrm{~mm}$ to $0.33 \mathrm{~mm}$ in diameter. The tip of the tail is bluntly pointed. Its reproductive organs include a pair of ovaries, oviducts, seminal receptacle, uteri and a long oviduct, vagina and vulva. The vulva has prominent lips at a distance of about 5 to 10 $\mathrm{mm}$ from the tip of the tail, that is about at oneeighth to one-tenth of the body length. The uteri of a mature female are filled with eggs and more or less obscuring the other organs. The eggs are oval shaped, enclosed in double membrane and always contain embryos. They measure $57 \times 33$ $\mu \mathrm{m}$ in diameter. Eggs are released into the external environment along with the faeces. ${ }^{92}$

Fibiger and Ditlevsen were the first to decipher the life cycle in 1914 (Figures 6\&7). ${ }^{41}$ The embryonated eggs are ingested by cockroaches while feeding on contaminated rat faeces containing the embryo. The embryonic membranes are dislodged in the gut, liberating the embryos which then penetrate the cockroach's muscles and commence development. After five to six weeks they appear as small transparent threadlike, spirally-coiled larvae. They are covered in cysts having a thin capsule. Each larva is about $250 \mu \mathrm{m}$ long. After three weeks, they undergo moulting and develop digestive system. Unlike other closely related roundworms for which the larvae are contained in the fatty bodies of the cockroaches, those of $G$. neoplasticum are embedded in the cross-striated muscle. Rats acquire infection with the larvae from eating infected cockroaches. The cysts are removed in the digestive tract of rat, liberating free juvenile worm. The worms gradually grow and reach sexual maturity in 60 days. $^{93}$

\section{References}

I. Dronamraju, K. (20I0). J. B. S. Haldane's last years: His life and work in India (1957-1964). Genetics. 185 (I): 5-IO. Doi:Io.I534/genetics.IIO.II6632.

2. Mukherjee, S. (20II). The Emperor of All Maladies: $A$ Biography of Cancer. New York (US): Scribner (Simon and Schuster, Inc.). pp. 47-48. ISBN 978-I-439I-709I-5.

3. Hayter, C. (2003). Cancer: "The Worst Scourge of Civilized Mankind". Canadian Bulletin of Medical History. 
20 (2): 25I-264. Doi:I0.3138/cbmh.20.2.25I.

4. Hajdu, S. I. (2004). Greco-Roman thought about cancer. Cancer. 100 (IO): 2048-205I. Doi:Io.IOO2/ cncr.20198.

5. Papavramidou, N., Papavramidis, T., Demetriou, T. (2010). Ancient Greek and Greco-Roman methods in modern surgical treatment of cancer. Annals of Surgical Oncology. 17 (3): 665-667. Doi:I0.I245/sio434-009-08866.

6. Keil, H. (1949). The evolution of the term chancre and its relation to the history of syphilis. Journal of the History of Medicine and Allied Sciences. 4 (4): 407-416. Doi:Io.I093/jhmas/IV.4.407.

7. Dirckx, J. (1983). Dermatologic terms in the De Medicina of Celsus. American Journal of Dermatopathology. 5 (4): $363-370$.

8. Hecht, F. (1987). On the origins of cancer genetics and cytogenetics. Cancer Genetics and Cytogenetics. 29 (I): 187-190. Doi:10.1016/or65-4608(87)90050-I.

9. Sambon, L.W. (1924). The elucidation of cancer. Proceedings of the Royal Society of Medicine. 17: 77-124.

Io. Reuben, A. (2005). The crab, the turkey and a malignant tale from the year of the rooster. Hepatology. 4I (4): 944-950. Doi:I0.I002/hep.20674.

II. Skuse, A. (2015). What was Cancer? Definition, Diagnosis and Cause. Constructions of cancer in Early Modern England. UK: Palgrave Macmillan. pp. 20-39. ISBN 978-I-I37-56919-6.

I2. Haddow, A. (1936). Historical notes on cancer from the mss. of Louis Westenra Sambon. Proceedings of the Royal Society of Medicine. 29: IOI5-IO28. Doi:I0.1177/00359157360290090I.

13. Shelfer, L. (2009). The alchemy of jargon: Etymologies of urologic neologisms. Number 5: Oncology and its vocabulary. The Prostate. 69 (13): 1369-I37I. Doi:Io.IOO2/pros.20979.

14. Kampen, K. R. (2012). The discovery and early understanding of leukemia. Leukemia Research. 36 (I): 6-I3. Doi:Io.IoI6/j.leukres.2011.09.028. PMID 2203319I.

I5. Degos, L. (200I). John Hughes Bennett, Rudolph Virchow... and Alfred Donné: the first description of leukemia. The Hematology Journal. 2 (I): I. Doi:10.1038/sj/ thj/620009o. PMID II920227.

16. Hirsch, E. F., Ingals, M. (1923). Sacrococcygeal chor- doma. JAMA: The Journal of the American Medical Association. 80 (19): 1369. Doi:Io.Iool/ jama.1923.02640460019007.

17. Cardesa, A., Zidar, N., Alos, L., Nadal, A., Gale, N., Klöppel, G. (201I). The Kaiser's cancer revisited: was Virchow totally wrong? Virchows Archiv. 458 (6): 649657. Doi:10.1007/s00428-01I-I075-0.

18. Virchow, R. (1858). Reizung und Reizbarkeit. Archiv für patbologische Anatomie und Physiologie und für klinische Medizin. I4 (I): I-I6.

19. Krämer, G. (2008). Hirntumor nach trauma: Literaturübersicht und begutachtungsproblematik [Brain tumor following trauma: Review of the literature and medico-legal considerations]. Aktuelle Neurologie. 09 (3): II2-I2O. Doi:I0.IO55/s-2007-IO2092I.

20. Coussens, L. M., Werb, Z. (2002). Inflammation and cancer. Nature. 420 (6917): 860-867. Doi:Io.I038/ natureor322.

2I. Fujiki, H., Sueoka, E., Suganuma, M. J. (2013). Tumor promoters: from chemicals to inflammatory proteins. Journal of Cancer Research and Clinical Oncology. 139 (Io): 1603-I6I4. Doi:I0.I007/soo432-0I3-I455-8.

22. Bainbridge, W. S. (1914). The Cancer Problem. Toronto (Canada): The Macmillan Company. pp. 39-44. ISBN 978 II 43385537.

23. Groth, H. (I865). Ueber das Vorkommen von Trichinen. Wurzberg (Germany): Druck Der C.J. Becker'schen Buchdruckerei. pp. 8-9.

24. Parkes, E.A. (1865). Report on Hygiene for the Year I863. In Statistical, Sanitary, and Medical Reports Volume $V$ (Presented to Both Houses of Parliament). London (UK): British Army Medical Department. p. 436.

25. Klopsh (I866). Fall von Trichinen-Erkrankung im Jahre I842. Volkommene Genesung. Entdeckung eingekapselter lebender Muskeltrichinen 24 Jahre nach der Invasion. Archiv für pathologische Anatomie und Physiologie und für klinische Medizin. 35: 609-6ro.

26. Anon. (I866). Trichina in a cancerous tumour. Journal of Materia Medica. 5 (I): 293-294.

27. Anon. (1866). Trichina in a cancerous tumour. Medical News and Library. 24 (277): II5.

28. Paget, J. (1887). The Morton Lecture on The Morton Lecture on Cancer and Cancerous Diseases. The British Medical Journal. 2 (I403): I09I-I094. Doi:Io.II36/ 
bmj.2.I403.IO9I.

29. Raju, T.N.K. (1998). The Nobel chronicles. The Lancet. 352 (9140): 1635. Doi:10.1016/Sor40-6736(98)ooo67-I.

30. Anon (2014). The Nobel Prize in Physiology or Medicine 1926. www.nobelprize.org. Nobel Media AB. Retrieved II January 2017.

31. Wernstedt, W. (1927). Award Ceremony Speech. www.nobelprize.org. Nobel Media AB.

32. Hróbjartsson, A., Gøtzsche, P.C., Gluud, C. (1998). The controlled clinical trial turns Ioo years: Fibiger's trial of serum treatment of diphtheria. The British Medical Journal. 317 (7167): 1243-I245. PMID 9794873.

33. Stolley, P. D. (1992). Johannes Fibiger and his Nobel Prize for the hypothesis that a worm causes stomach cancer. Annals of Internal Medicine. $\mathbf{I 1 6}$ (9): 765-769. Doi:10.7326/0003-4819-116-9-765.

34. Galeb, M. O. (1878). Observations and experiments on the migrations of Filaria rbytipleurites, a parasite of cockroaches and rats. Journal of Natural History Series 5. 2 (8): 199-200. Doi:I0.1080/00222937808694080.

35. Modlin, I.M., Kidd, M., Hinoue, T. (200I). Of Fibiger and fables: a cautionary tale of cockroaches and Helicobacter pylori. Journal of Clinical Gastroenterology. 33 (3): I77-I79. PMID II500602.

36. Weisse, A. B. (2015). Barry Marshall and the resurrection of Johannes Fibiger. Hospital Practice. 3I (9): I05-II6. Doi:Io.1080/2I548331.1996.II443349.

37. Stolt, C.-M., Klein, G., Jansson, A.T.R. (2004). An analysis of a wrong Nobel Prize-Johannes Fibiger, 1926: A study in the Nobel Archives. In Woude, G.F.V.; Klein, G. Advances in Cancer Research. California (US): Elsevier Academic Press. p. 4. ISBN 9780080522296.

38. Fibiger, J. (1913). Untersuchungen über eine Nematode (Spiroptera sp. n.) und deren Fähigkeit, papillomatöse und carcinomatöse Geschwulstbildungen im Magen der Ratte hervorzurufen. Zeitschrift für Krebsforschung. I3 (2):217-28o. Doi:10.1007/BFo2218682.

39. Fibiger, J. (1913). Ueber eine durch Nematoden (Spiroptera sp. n.) hervor-gerufene papillomatose und carcinomatose Geschwulstbildung im Magen der Ratte. Berliner Klinische Wochenschrift. 5o: 289-298.

40. Fibiger, J. (1913). Recherches sur un nématode et sur sa faculté de provoquer des néoformations papillomateuses et carcinomateuses dans l'estomac du rat. l'Acadé- mie royale des sciences et des lettres du Danemark. Extrait du bulletin de l'année No. I.

4I. Fibiger, J., Ditlevsen, H. (1914). Contributions to the biology and morphology of Spiroptera (Gongylonema) neoplastica n. sp. Mindeskrift $i$ anledning af hundredaaret for Japetus Steenstrups fodsel: 25: I-28 (with plates +8 pages). http://runeberg.org/japetusioo/xxv

42. Fibiger, J. (1919). On Spiroptera carcinomata and their relation to true malignant tumors; with some remarks on cancer age. The Journal of Cancer Research. 4 (4): 367-387. Doi:Io.II58/jcr.1919.367.

43. Slye, M. (1924). The Fundamental Harmonies and the Fundamental Differences between Spontaneous Neoplasms and All Experimentally Produced Tumors: Studies in the Incidence and Inheritability of Spontaneous Cancer in Mice: Twentieth Report. The Journal of Cancer Research. 8 (2): 240-273. Doi:Io.II58/jcr.1924.240.

44. Fibiger, J. (1927). Nobel Lecture: Investigations on Spiroptera Carcinoma and the Experimental Induction of Cancer. www.nobelprize.org. Retrieved II January 2017.

45. Borrel, A. (1906). Tumeurs cancereuses et helminthes [Cancerous tumours and helminths]. Bulletin de l'Académie nationale de médecine. 56: I4I-I45.

46. Borrel, A. (1927). Étiologie vermineuse de certaino cancers [Helminthic origin of certain cancers]. Compte Rendu de l'Academie des Sciences. I84: 632-634.

47. Ward, H.B. (1916). Gongylonema in the role of a human parasite. The Journal of Parasitology. 2 (3): II9-I25.

48. Anon (1926). Rats, worms, and cancer. The British Medical Journal. I (3414): IOO2-IOO3.

49. Balkwill, F., Mantovani, A. (200I). Inflammation and cancer: back to Virchow? The Lancet. 357 (9255): 539545. Doi:Io.roi6/Sor40-6736(oo)04046-o.

5o. Yamagiwa, K., Ichikawa, K. (1918). Experimental study of the pathogenesis of carcinoma. The Journal of Cancer Research. 3 (I): I-29. Doi:Io.II58/jcr.I9I8.I.

5I. Narat, J. K. (1925). Experimental production of malignant growths by simple chemicals. The Journal of Cancer Research. 9 (I): 135-I47. Doi:IO.II58/jcr.I925.I35.

52. Rota, M., Bosetti, C., Boccia, S., Boffetta, P., La Vecchia, C. (2014). Occupational exposures to polycyclic aromatic hydrocarbons and respiratory and urinary tract cancers: an updated systematic review and a metaanalysis to 2014. Archives of Toxicology. 88 (8): 1479- 
I490. Doi:10.1007/s00204-OI4-I296-5.

53. Alicandro, G., Rota, M., Boffetta, P., La Vecchia, C. (2016). Occupational exposure to polycyclic aromatic hydrocarbons and lymphatic and hematopoietic neoplasms: a systematic review and meta-analysis of cohort studies. Archives of Toxicology. 90 (II): 2643-2656. Doi:10.1007/soo204-016-1822-8.

54. McCoy, G.W. (1909). A preliminary report on tumors found in wild rats. The Journal of Medical Research. 2I (2): 285-296. PMID 19971919.

55. Bullock, P. D., Rohdenburg, G. L. (1917). Spontaneous tumors of the rat. The Journal of Cancer Research. 2 (I): 39-6o. Doi:Io.II58/jcr.1917.39.

56. Dunning, W.F., Curtis, M.R. (1953). Attempts to isolate the active agent in Cysticercus fasciolaris. Cancer Research. I3 (12): 838-842. PMID I3II6I2I.

57. Anon. (20I4). Johannes Fibiger - Nominations. www.nobelprize.org. Nobel Media AB. Retrieved II January 2017.

58. Norrby, E. (2010). Nobel Prizes and Life Sciences. Singapore: World Scientific Publishing Co. Pte. Ltd. p. II5. ISBN 9789814299374.

59. Bullock, F. D., Rohdenburg, G. L. (1918). Experimental "carcinomata" of animals and their relation to true malignant tumors. The Journal of Cancer Research. 3 (3): 227-273. Doi:Io.II58/jcr.I9I8.227.

6o. Passey, R. D., Leese, A., Knox, J. C. (1935). Spiroptera cancer and diet deficiency. Journal of Pathology and Bacteriology. 40 (I): 198-199.

6I. Cramer, W. (1937). Papillomatosis in the forestomach of the rat and its bearing on the work of Fibiger. The American Journal of Cancer. 31 (4): 537-555. Doi:Io.II58/ajc.1937.537.

62. Hitchcock, C. R., Bell, E. T. (1952). Studies on the nematode parasite, Gongylonema Neoplasticum (Spiroptera Neoplasticum), and avitaminosis a in the forestomach of rats: Comparison with Fibiger's results. Journal of the National Cancer Institute. 12 (6): 1345-1387. Doi:Io.I093/jnci/r2.6.1345.

63. Oettlé, A. G. (1962). A historical review of past histopathological material at the South African Institute for Medical Research between I9II and 1927. South African Medical Journal. 36 (31): 628-631.

64. Doldo, E., Costanza, G., Agostinelli, S., Tarquini, C.,
Ferlosio, A., Arcuri, G., Passeri, D., Scioli, M. G., Orlandi, A. (2015). Vitamin A, cancer treatment and prevention: The new role of cellular retinol binding proteins. BioMed Research International. 624627: I-I4. Doi:10.II55/2015/624627.

65. Burrows, M. T., Jorstad, L. H., Ernst, E. C. (1926). The effect of X-Rays on the vitamin needs of the organism and cancer. Radiology. 7 (4): 279-29I. Doi:Io.II48/7.4.279.

66. Burrows, M. T. (1926). Studies on the nature of the growth stimulus in cancer. The Journal of Cancer Research. Io (2): 239-25I. Doi:Io.II58/jcr.1926.239.

67. Burrows, M. T. (1926). Cancer, Vitamin imbalance, and Roentgen-ray activity. JAMA: The Journal of the American Medical Association. 87 (2): 86. Doi:Io.IooI/ jama.1926.02680020014004.

68. Burrows, M. T. (1926). The effect of vitamin feeding on the growth of cancer. Experimental Biology and Medicine. 24 (I): 88-90. Doi:Io.318I/o0379727-24-3240.

69. Fujimaki, Y. (1926). Formation of gastric carcinoma in albino rats fed on deficient diets. The Journal of Cancer Research. Io (4): 469-477. Doi:Io.II58/jcr.1926.469.

70. Tyson, M. D., Smith, A. H. (1929). Tissue changes associated with Vitamin A deficiency in the rat. The American Journal of Pathology. S (I): 57-70. PMID 19969830.

71. Sugiura, K., Benedict, S. R. (1930). A critical study of vitamin $A$ and carcinogenesis. The Journal of Cancer Research. 14 (2): 306-3IO. Doi:Io.II58/jcr.1930.306.

72. Sugiura, K., Benedict, S. R. (1930). The influence of high fat diets on the growth of carcinoma and sarcoma in rats. The Journal of Cancer Research. I4 (2): 3II-3I8. Doi:Io.II58/jcr.1930.3II.

73. Kuh, C. (1932). A study of vitamin A in relation to experimental cancer. The Yale Journal of Biology and Medicine. 5 (2): 123-I53. PMID 2I433557.

74. Sure, B., Buchanan, K. S., Thatcher, H. S. (1936). Vitamin $\mathrm{A}$ and carcinogenesis. The American Journal of Cancer. 27 (I): 84-86. Doi:Io.II58/ajc.1936.84.

75. Schneider, E. (1937). Zur Klinik hypovitaminotischer Zustande bei der Krebskrankheit [Vitamin deficiency in persons suffering from cancer]. Archiv für klinische Chirurgie. 190: 397-413.

76. Moir, J. L. (1938). Cancer and vitamin A deficiency: Geographical distribution. The British Medical Journal. 
I (4024): 42I-42I. Doi:Io.II36/bmj.I.4024.42I-a.

77. Hastings, V. E. (1938). Cancer and vitamin A deficiency. The British Medical Journal. I (4042): 1390.

78. Clemmesen, J. (1978). Johannes Fibiger. Gongylonema and vitamin A in carcinogenesis. Acta Pathologica et Microbiologica Scandinavica. 270 (Suppl.): I-I3. PMID 362817 .

79. Watts, G. (2005). Nobel prize is awarded to doctors who discovered Hpylori. The British Medical Journal. 331 (7520): 795-795. Doi:Io.1136/bmj.331.7520.795.

8o. Marshall, B. (2008). Helicobacter pylori-a Nobel pursuit? Canadian Journal of Gastroenterology. 22 (II): 895896. PMID 19018331.

8I. Anon. (1928). Obituary: Johannes Fibiger, M.D. The British Medical Journal. I (3500): 200. PMID 20773676.

82. Weisse, A. B. (1998). The Staff and the Serpent: Pertinent and Impertinent Observations on the World of Medicine. Carbondale (US): Southern Illinois University Press. p. 83. ISBN 9780809321490.

83. Baylis, H.A. (1925). On Gongylonema collected in Italy during October, 1924, with some observations on the genus. Journal of Tropical Medicine and Hygiene. 28 (3): $7 \mathrm{I}-76$.

84. Lalchhandama, K. (2014). The making of modern malariology: from miasma to mosquito-malaria theory. Science Vision. 14 (I): 3-17.

85. Manson, P. (1900). Experimental proof of the mosquito -malaria theory. The Lancet. I56 (4022): 923-925. Doi:Io.Ior6/Sor40-6736(or)86862-8.
86. Capanna, E. (2006). Grassi versus Ross: who solved the riddle of malaria? International Microbiology. 9 (I): 6974. PMID i6636993.

87. Fibiger, J. (1914). Weitere Untersuchungen über das Spiroptera carcinom der Ratte. Zeitschrift für Krebsforschung. 14: 295 .

88. Fibiger, J., Bang, F. (19I8). Investigations on the Spiroptera Cancer. V: On the growth of small carcinomata and on predisposition to Spiroptera Cancer in rats and mice. Det Kongelige Danske Videnskabernes Selskab Biologiske Meddelelser. I: II.

89. Fibiger, J., Bang, F. (1920). Sur la transmission aux rats de la Spiroptera neoplastica (Gongylonema neoplasticum). Comptes Rendus Des Seances De La Societe De Biologie Et De Ses Filiales j. 83: II57-II6o.

90. Ditlevsen, H. (1918). Über Gongylonema neoplasticum (Spiroptera (Gongylonema) neoplastica Fibiger et Ditlevsen). Zentralblatt für Bakteriologie, Mikrobiologie und Hygiene. I. Abteilung Originale. 81: 565-576.

9I. Kruidenier, F. J., Peebles, C. R. (1958). Gongylonema of rodents: G. neoplasticum (redefinition), G. dipodomysis n. sp., and G. peromyscin. sp. Transactions of the American Microscopical Society. 77 (3): 307-315.

92. Yokogawa, S. (1925). On a new species of nematode, Gongylonema orientale, found in Formosa. The Journal of Parasitology. II (4): 195-200. Doi:10.2307/3270828.

93. Ransom, B.H., Hall, M.C. (1915). The life-history of Gongylonema scutatum. Journal of Parasitology. 2 (2): 80 -86. Doi:10.2307/3271023. 